\title{
Dhanwantharam Kashayam for Preventing Post- Partum Complications in Cross-Bred Cows
}

\author{
Suresh Bharath ${ }^{1}$, Puniamurthy $\mathrm{N}^{2}$ and Nair $\mathrm{MNB}^{3 *}$ \\ ${ }^{1}$ Veterinary surgeon, AHD, Government of kerala, India \\ ${ }^{2}$ Veterinary University Training and Research centre, Tanuvas, Thanjavur \\ ${ }^{3}$ Ethno Veterinary Sciences, Group Trans-disciplinary University, Bangalore, India
}

Submission: December 29, 2017; Published: April 03, 2018

*Corresponding author: Nair MNB, Ethno of Veterinary Sciences, Group Trans-disciplinary University, Bangalore-560106, India,

Email: nairmnb@tdu.edu.in

\begin{abstract}
Dhanwantharam Kashayam (DK) - The herbal formulation in the form of a decoction - mentioned in Astangahridayam, prevents post-partum complications in cross-bred cows under field conditions. Cross-bred cows during the third trimester of pregnancy, administered with $250 \mathrm{ml}$ of DK twice daily till parturition were devoid of post-partum oedema and post-calving stress after delivery. All the treated cows except one shed their fatal membrane after delivery within two to six hours. Only one animal exhibited difficulty in parturition because of twin pregnancy. The analysis of serum samples of treated cows for albumin, globulin, blood urea nitrogen, total protein, creatinine kinase, glucose, aspartate transaminase, alkaline phosphatase, gamma-glutamyltranspeptidase, serum calcium, phosphorous, magnesium and iron, before and after parturition showed near normal levels. The result indicated that pre-partum administration of DK for thirty days to cross-bred cows did not show the post- partum complications like retention of fetal membrane, post-partum oedema and post-calving stress.
\end{abstract}

Keywords : Post-partum complications; Cross bred cows; Dhanvantram kashayam

Abbreviations : DK: Dhanwantharam Kashayam; GGT: Gama G-lutamyl Transpeptidase; ALP: Alkaline Phosphatise; AST: Aspartate transaminase

\section{Introduction}

The present intensive dairy production systems using exotic cow breeds with a very high per-animal productivity target has mandated improved management of these cows. Disturbance or mismanagement during the transition period will damage the reproductive tract and oocytes of the dairy cow and indirectly interfere with the normal hypothalamic pituitary-ovarian hormonal control system [1]. Foetal membranes are normally expelled within 12 hours of parturition. If expulsion happen between 12-24 hours it is considered as delayed and not expelled within 24 hours are considered as retained. The reported incidence of retained placenta is $24.3 \%$ [2]. The udder is also prone to injury due to post-partum oedema. The persistent oedema interferes with the milking and may lead to predispose mastitis. Udder oedema also leads to losses in dairy industry due to decreased milk production. Endometritis following parturition is a major cause of infertility in dairy animals leading to delayed pregnancy and resumption of reproduction after parturition. The incidence of uterine bacterial infection has not decreased in spite of wide spread use of antibiotics. Use of DK during pregnancy (pre and post-natal period) in humans is well documented in Ayurveda (Astangahridayam). It helps to overcome parturition stress by strengthening the pelvic muscle, ligaments for easy delivery, involution and shedding of placenta. Present study was undertaken to evaluate the clinical efficiency of DK in cross bred cows during transition period.

\section{Materials and Methods}

Eleven cross bred animals of last trimester (above 250 days of pregnancy) of pregnancy were selected for this study. All the animals were belonging to Thirur and Kottakkal of Malappuram (Dt), Kerala State. Inclusion and exclusion criteria are given in Table 1.

Table 1: Inclusion and exclusion criteria.

\begin{tabular}{|c|c|c|}
\hline No & Inclusion criteria & Exclusion criteria \\
\hline 1 & Only cross bred animals & Local breed \\
\hline 2 & $1^{\text {st }}, 2^{\text {nd }}$ or $3^{\text {rd }}$ pregnancy & Above 4thpregnancy \\
\hline 3 & $\begin{array}{c}\text { Known to have RoP in the } \\
\text { previous delivery }\end{array}$ & ----------- \\
\hline 4 & $\begin{array}{c}\text { No diagnosed disease(s) } \\
\text { when selected }\end{array}$ & $\begin{array}{c}\text { Undergoing treatment for any } \\
\text { clinical conditions }\end{array}$ \\
\hline
\end{tabular}




\section{Journal of Dairy and Veterinary Sciences}

\section{a. Treatment protocol}

The DK (Table 2) powder (375gms) was boiled with fifteen litres of water on moderate fire till it was reduced to 5 litres. $250 \mathrm{ml}$ of this decoction was administered twice daily to each cow orally by mixing it in the feed. The decoction was boiled every day to avoid contamination with microbes. After every 10 days new decoction is prepared. The treatment is continued for 30 days. Before administration of DK, serum analysis was conducted for GGT (Gamma Glutamyl-transpeptidase), ALP (AlkaLine Phosphatase), AST (ASpartate Transaminase), calcium, Magnesium, Phosphorus, Iron, Serum, albumin, Serum globulin, Total protein, Blood urea, Nitrogen, Glucose, Creatin kinase [3] and examined for presence of Pre-partum oedema in all animals. After calving, Serum analysis of the same animals was repeated as mentioned above. Presence of post-partum oedema, time taken for shedding of placenta and post calving stress (ie. staggering gait, anorexia, shock) were recorded.

Table 2: Dhanwantharam Kashayam Ingredients.

\begin{tabular}{|c|c|c|c|}
\hline No & Name of the Ingredient & Local Name & Quantity \\
\hline 1 & Acorus calamus L. & Vacha (Rhizome) & $0.04 \%$ \\
\hline 2 & Aegle marmelos (L.) Corrêa & Indian Bael & $5.20 \%$ \\
\hline 3 & Anethum graveolens L. & Soya (Dill) - (Anethum Sowa) & $0.04 \%$ \\
\hline 4 & Aquilaria agallocha Roxb. & Agaru & $0.04 \%$ \\
\hline 5 & Asparagus racemosusWilld. & Shatavari & $0.04 \%$ \\
\hline 6 & Boerhavia diffusa L. nom. cons. & Punarnava & $0.04 \%$ \\
\hline 7 & Cedrus deodara(Roxb.) G.Don & $\begin{array}{c}\text { Devdaru (Deodar/ Himalayan } \\
\text { cedar }\end{array}$ & $0.04 \%$ \\
\hline 8 & $\begin{array}{l}\text { Cinnamomum tamala (Buch.- } \\
\text { Ham.) T.Nees \& C.H.Eberm }\end{array}$ & Tejpata (Indian Bay Leaf) & $0.04 \%$ \\
\hline 9 & Cinnamomum zeylanicum Blume & Dalchini (Cinnamon) & $0.04 \%$ \\
\hline 10 & Desmodium gangeticum (L.) DC. & Shalaparni & $5.20 \%$ \\
\hline 11 & Dolichos biflorus L & Kulthi (Horse gram) & $5.20 \%$ \\
\hline 12 & $\begin{array}{c}\text { Elettaria cardamomum (L.) Maton } \\
-\end{array}$ & Elaichi (Cardamom) & $0.04 \%$ \\
\hline 13 & Fritillaria roylei - Hook.f. & Kakoli & $0.04 \%$ \\
\hline 14 & Glycyrrhiza glabraL & Yashtimadhu (Licorice) & $0.04 \%$ \\
\hline 15 & Gmelina arborea Roxb. & Gambhari (Beech wood/Kasmari) & $5.20 \%$ \\
\hline 16 & Hemidesmus indicus (L.) R.Br. & Sariva & $0.04 \%$ \\
\hline 17 & Hordeum vulgare L. & Yava ( Barley grain) & $5.20 \%$ \\
\hline 18 & $\begin{array}{l}\text { Ichnocarpus frutescens (L.) } \\
\text { W.T.Aiton }\end{array}$ & $\begin{array}{c}\text { Kalidudhi (Kalanusari OR Black } \\
\text { Creeper) }\end{array}$ & $0.04 \%$ \\
\hline 19 & Lilium polyphyllum D.Don & KsheeraKakoli & $0.04 \%$ \\
\hline 20 & Microstylis muscifera (Lindl.) Ridl. & Rishabhaka & $0.04 \%$ \\
\hline 21 & Microstylis wallichii Lindl. & Jeevak & $0.04 \%$ \\
\hline 22 & olygonatum verticillatum (L.) All & Mahameda & \\
\hline 23 & $\begin{array}{l}\text { Oroxylum indicum(L.) Benth. ex } \\
\text { Kurz }\end{array}$ & Shyonaka & $5.20 \%$ \\
\hline 24 & Parmelia perlata Ach. & Shaileyam & $0.04 \%$ \\
\hline 25 & Phaseolus trilobus Ait. & Mudgaparni & \\
\hline 26 & Phyllanthus emblicaL. & Amla & \\
\hline 27 & $\begin{array}{l}\text { Polygonatum cirrhifolium (Wall.) } \\
\text { Royle }\end{array}$ & Meda & $0.04 \%$ \\
\hline 28 & $\begin{array}{l}\text { Polygonum verticillatum Biroli ex } \\
\text { Colla }\end{array}$ & Medaa, Whorled Solomon's Seal & $0.04 \%$ \\
\hline 29 & Premna serratifolia L & Agnimantha (Arani) & $5.20 \%$ \\
\hline 30 & Pterocarpus santalinus L.f. & LalChandan (Red Sandalwood) & $0.04 \%$ \\
\hline 31 & Rock salt & Sendha namak & $0.04 \%$ \\
\hline
\end{tabular}


Journal of Dairy and Veterinary Sciences

\begin{tabular}{|c|c|c|c|}
\hline 32 & Rubia cordifolia L. & Manjistha & $0.04 \%$ \\
\hline 33 & Saussurea lappa C.B Clarke & Kushta (Indian Costus Root) & $0.04 \%$ \\
\hline 34 & Sida cordifolia L. & Bala (Root) & $31.21 \%$ \\
\hline 35 & Solanum indicum L. S. Ferox L. NoN & Ambig & $5.20 \%$ \\
\hline 36 & Solanum surattense Burm. F. & Kantakari & $5.20 \%$ \\
\hline 37 & Stereosprmum sauvealens DC (S. \\
& colais), & Paatala & $5.20 \%$ \\
\hline 38 & Teramnus labialis (L.) Spreng. & Mashaparni & $0.04 \%$ \\
\hline 39 & Terminalia bellirica (Gaertn.) Roxb. & Bibhitaki & $0.04 \%$ \\
\hline 40 & Terminalia chebula Retz. & Haritaki & $0.04 \%$ \\
\hline 42 & Tribulus terrestris L. & Gokshura & $5.20 \%$ \\
\hline 43 & Uraria picta (Jacq.)DC. & Prishnaparni & $5.20 \%$ \\
\hline
\end{tabular}

\section{Result and Discussion}

Serum profile of total protein, albumin, globulin, glucose, blood urea nitrogen, mineral profiles and liver enzymes were shown in Table 4. In cross bred animals, after delivery there is a drop in calcium level during early stage of lactation $(8.19 \pm$ $0.83 \mathrm{mg} / \mathrm{dl})$ than the normal healthy cows $(11.21 \pm 0.19 \mathrm{mg} /$ dl). After delivery calcium level in blood is below $6.4 \mathrm{mg} /$ dl (Hypocalcaemia) [4]. The reduced $\mathrm{Ca}++$ levels could be a result of the impaired absorption of food metabolites from the gastrointestinal precursor, excessive losses through urine, production colostrums as it was much more drained in the colostrums during excessive milking and due to insufficient mobilization from the skeleton. As the stage of lactation progresses the serum calcium level attains desired level. Serum calcium has been reported to show a tendency to decrease shortly after calving. Moderate depression in the levels of phosphorus after delivery might be due to the necessity of it for the colostrums synthesis and enhanced carbohydrate metabolism.

All the animals treated with Dhanwantharam kashayam showed normal levels of blood calcium. Magnesium plays a vital role during the metabolism of carbohydrates, lipids, nucleic acids and proteins. Magnesium promotes vasodilatation and uterine relaxation. Medication of pregnant cows with DK during pregnancy showed significant maintenance of mineral status after delivery. It was observed that there is no drastic reduction in mineral status after delivery in the treated animals. A high $\mathrm{Ca} / \mathrm{Mg}$ ratio was maintained before and after the delivery. This may be reason for normal calving procedure and lesser postpartum complications. Medicated cows showed normal calcium, magnesium and phosphorous levels in their blood indicating that drug helps to restore mineral imbalance after calving (Table 4).

A high $\mathrm{Ca} / \mathrm{Mg}$ ratio has been experimentally shown to provoke vasospasm in certain blood vessels in vitro and is responsible for the spasm of umbilical and placental vasculature at the end of pregnancy. It is likely that the intake of magnesium supplement may help to reduce the incidence of dystocia. Medicating the cows with DK during pregnancy significantly reduces the time for shedding of foetal membranes after delivery and the time taken for shedding the placenta is two to six hours (Table 3). Out of the eleven cows studied, all of them except one shed their foetal membranes within two to six hours.

Table 3: Details of the Animals selected for the Study before and after Treatment.

\begin{tabular}{|c|c|c|c|c|c|c|}
\hline No. & Type of Animal & Pre-Partum Oedema & Dystocia & $\begin{array}{c}\text { Placenta Shedding } \\
\text { Time }\end{array}$ & $\begin{array}{l}\text { Post-Partum } \\
\text { Oedema }\end{array}$ & $\begin{array}{l}\text { Post Calving } \\
\text { Stress }\end{array}$ \\
\hline 1 & $\begin{array}{c}\text { CB Heifer } 21 / 2 \\
\text { yrs }\end{array}$ & * & Nil & $4 \mathrm{hrs}$ & $*$ & Nil \\
\hline 2 & CBBS 6 yrs & $* *$ & Nil & $4 \mathrm{hrs}$ & $*$ & Nil \\
\hline 3 & CB 5 yrs & $* *$ & Nil & $4 \mathrm{hrs}$ & $*$ & Nil \\
\hline 4 & CBJ 5yrs & $*$ & Nil & $6 \mathrm{hrs}$ & $*$ & Nil \\
\hline 5 & CB Hefier 3 yrs & * & Nil & $4 \mathrm{hrs}$ & $*$ & Nil \\
\hline 6 & CB Heifer 2 yrs & $* * *$ & Nil & $6 \mathrm{hrs}$ & $* *$ & Nil \\
\hline 7 & CB 5yrs & $* *$ & Nil & $4 \mathrm{hrs}$ & $* *$ & Nil \\
\hline 8 & CB Heifer 2.5 yrs & $* * *$ & Nil & $4 \mathrm{hrs}$ & $* *$ & Nil \\
\hline
\end{tabular}


Journal of Dairy and Veterinary Sciences

\begin{tabular}{|c|c|c|c|c|c|c|}
\hline 9 & CB Heifer 3 yrs & $* *$ & Nil & 4 hrs & $*$ & Nil \\
\hline 10 & CBJ 5 yrs & $*$ & Nil & $3 \mathrm{hrs}$ & $*$ & Nil \\
\hline 11 & CBJ cow 6 yrs & $*$ & Nil & $2 \mathrm{hrs}$ & $*$ & Nil \\
\hline
\end{tabular}

Incidence of dystocia is common in cross bred animals. Reasons for this can be attributed to the inertia of uterine musculature during delivery. In both clinical studies and Ayurveda treatment, it has been proved that DK helps to regain uterine muscular tone and fastens uterine involution after delivery. DK is the drug of choice for regaining uterine muscular tone during parturition. It helps to overcome parturition stress by strengthening the pelvic muscles, ligaments, for easy delivery. Third stage labour, involution and shedding of foetal membrane were fastened by this medication. Ten out of the eleven cows showed normal and easy delivery. And one case of dystocia was observed due to twin pregnancy (Table 3). These animals showed markedly reduced stress levels after delivery and showed normal feeding, rumination and absence of lameness. Medication with Dhanwandharam Kashayam during pregnancy can effectively control pre and post-partum "oedema". Cows with post-partum oedema have reduced blood urea nitrogen level and increased total protein in their blood [5].

Table 4: Serum values of pregnant and treated calved cows.

\begin{tabular}{|c|c|c|c|}
\hline Sl.no & Item & Pregnant & $\begin{array}{c}\text { After Calving } \\
\text { (Treated) }\end{array}$ \\
\hline 1 & Albumin & $4.1 \pm 0.191$ & $3.88 \pm .101$ \\
\hline 2 & Globulin & $8.718 \pm 0.305$ & $3.70 \pm 0.35$ \\
\hline 3 & Total protein & $7.8 \pm 0.44$ & $7.5 \pm 0.313$ \\
\hline 4 & Glucose & $36 \pm 8.01$ & $26 \pm 3.19$ \\
\hline 5 & Creatin kinase & $88.91 \pm 12.88$ & $180.60 \pm 48.12$ \\
\hline 6 & Bun & $12.73 \pm 1.81$ & $10.6 \pm 1.42$ \\
\hline 7 & Alkaline phosphatase & $85.36 \pm 10.25$ & $64.4 \pm 7.07$ \\
\hline 8 & Aspartate transeaminase & $65.09 \pm 6.29$ & $81.1 \pm 9.02$ \\
\hline 9 & Gama glutamyl & $24.73 \pm 4.92$ & $21.20 \pm 2.55$ \\
\hline 10 & transaminase & $8.96 \pm 0.19$ & $8.59 \pm 0.386$ \\
\hline 11 & Calcium & $8.027 \pm 0.582$ & $6.53 \pm 0.522$ \\
\hline 12 & Phosphorus & $2.55 \pm 0.73$ & $2.91 \pm 0.20$ \\
\hline 13 & Magnesium & $74.09 \pm 10.50$ & $92.30 \pm 9.48$ \\
\hline & Iron & & \\
\hline
\end{tabular}

The medicated cows the level of blood urea nitrogen and total protein were normal. Gama G-lutamyl Transpeptidase (GGT), AlkaLine Phosphatise (ALP) and Aspartate transaminase (AST) are estimated for assessing liver function status and their normal range is 11-24 U/L, 14-38U/L, 78-132U/L respectively. After delivery post-partum stress may increase serum enzyme level, leading to lower liver function and may cause anorexia and decreased ruminal function. All the medicated animals showed normal ranges of serum enzyme level indicating normal liver function after delivery. They also showed normal feeding and rumination after calving. Uterine inertia, increased globulin, albumin-globulin ratio and increased total protein in blood after delivery are suggestive of endometritis leading to repeat breeding. Serum albumin, globulin and total protein are also estimated at third trimester of pregnancy, and are again estimated immediately after calving (Table 4).

All the eleven animals showed normal ranges of Serum albumin, globulin and proteins in their blood. Repeat breeding leads to increase inter calving period and may cause economic loss in dairy farming. During pregnancy supplementation with DK showed significantly improved uterine tone after delivery and blood parameters of albumin, globulin and total protein. Hence, incidence of endometritis is reduced after calving. This study of supplementation with Dhanwandharam Kashayam indicated control of post-partum complications. A study using larger number of cows is needed for detailed understanding of the effect of DK in reducing the post-partum complication in cattle.

\section{References}

1. Senthilkumar V, Mohamed Safiullah A, Kathiravan G, Subramanian M, et al. (2013) Economic Analysis of Metabolic Diseases in Bovines: A Review. International Journal of Advanced Veterinary Science and Technology 2(1): 64-71.

2. Mohanty KC, Mohanty BN, Ray SKH, Mohnty DB, (1994) Levels of glucose, calcium and alkaline phosphatase in blood with relation to retention of placenta in bovine. Indian J Anim Reprod 15: 21-25.

3. Pushkar P, Bhatta R (2013) Determinations of blood metabolites in cross HF cattle at Pre- parturient stage: reference value. Int J Pharm Med \& Bio Sc

4. Mordak R, Nicpoń J (2006) Values of Some Blood Parameters in Dairy Cows before and After Delivery as a Diagnostic Monitoring of Health in Herd. Electronic Journal of Polish Agricultural Universities. Series Veterinary Medicine 9(2)

5. Magnus PK, Lali F A (2014) Serum Biochemical Profile of Post-Partum Metritic Cow. Veterinary World 97(3): 1529-1534. 
This work is licensed under Creative Commons Attribution 4.0 License DOI: 10.19080/JDVS.2018.05.555666
Your next submission with Juniper Publishers will reach you the below assets

- Quality Editorial service

- Swift Peer Review

- Reprints availability

- E-prints Service

- Manuscript Podcast for convenient understanding

- Global attainment for your research

- Manuscript accessibility in different formats ( Pdf, E-pub, Full Text, Audio)

- Unceasing customer service

Track the below URL for one-step submission https://juniperpublishers.com/online-submission.php 